\title{
Efek Evaporasi Larutan Hasil Kromatografi pada Mobilitas Pembawa Muatan Lapisan Klorofil
}

\author{
Supatmi, ${ }^{*}$ Utari, dan Budi Purnama ${ }^{\dagger}$ \\ Jurusan Fisika, FMIPA Universitas Sebelas Maret Surakarta, Jl. Ir. Sutami No. 36 A, Surakarta 57126 \\ Intisari \\ Studi berkenaan mobilitas pembawa muatan lapisan Spirulina sp hasil karakterisasi I-V meter telah dilakukan. \\ Hasil menunjukkan bahwa nilai serapan sampel dari larutan hasil evaporasi lebih rendah dibandingkan hasil kro- \\ matografi. Karakterisasi I-V meter memperlihatkan peningkatan mobilitas untuk sampel larutan hasil evaporasi. \\ Mobilitas pembawa muatan sampel lapisan tipis dari larutan hasil evaporasi meningkat seiring peningkatan \\ jumlah lapisan dan menunjukkan nilai konstan untuk $\mathrm{N}>3$. Hal ini disumbang traping pembawa muatan yang \\ dominan untuk jumlah perulangan lapisan lebih banyak.
}

\begin{abstract}
Study on charge carrier mobility of Spirulina sp layers I-V meters characterization has been done. The results show that charge carrier mobility increases with the number of layers Spirulina sp. Charge carrier mobility for $\mathrm{N}>3$ showed a constant value. It is contributed trapping dominant charge carrier layers for the number of iteration more.
\end{abstract}

KATA KUNCI: Spirulina sp, I-V meters, mobility

\section{PENDAHULUAN}

Aspek menarik dalam proses fotosintesis adalah adanya tranduksi energi cahaya oleh pigmen yang terletak pada membran fotosintesis. Klorofil adalah pigmen warna yang diketahui memegang peranan penting dalam proses penangkapan cahaya dan mengubah menjadi bentuk lain pada saat berlangsungnya proses fotosintesis [1]. Selama proses fotosintesis berlangsung foton yang telah diserap menyebabkan klorofil tereksitasi dari keadaan ground state ke keadaan tereksitasi, yang merupakan awal terjadinya transfer elektron, dimana pada proses ini klorofil berperan sebagai donor dan aseptor muatan [2-4]. Struktur elektronik klorofil hingga sekarang masih menjadi perhatian para ilmuwan $[5,6]$.

Selain itu, molekul klorofil memiliki dimensi orde nanometer. Sehingga klorofil semakin menarik dikaji utamanya potensi realisasi piranti organik-elektronika orde nano meter. Selebihnya, material organik alam ini juga memiliki medan quantum flouresensi yang tinggi sehingga dapat diterapkan sebagai mikroskopi flouresensi serta sebagai donor dan aseptor pembawa muatan pada devais fotonik [7-10].

Klorofil dapat diisolasi dengan menggunakan metode kromatografi dari bahan alam seperti bayam [11] atau algae [12]. Selanjutnya hasil isolasi ini menjadi bahan dasar fabrikasi lapisan tipis yang dapat disiapkan dengan beragam metode fisika. Proses yang termasuk di dalam metode tersebut diantaranya evaporation, vapor deposition, spin coating, dan teknik deposisi Langmuir Blodgett [13].

\footnotetext{
*E-MAIL: supatmi@student.uns.ac.id

†E-MAIL: bpurnama@mipa.uns. ac.id
}

Pada penelitian ini akan dilakukan efek evaporasi hasil larutan kormatografi terhadap mobilitas pembawa muatan dari lapisan tipis klorofil Spirulina sp. Sampel lapisan tipis dideposisi dengan metode spin coating pada substrat printed board circuit (PCB). Akhirnya mobilitas pembawa muatan lapisan klorofil diukur dengan metode two point probe I-V meter.

\section{EKSPERIMEN}

\section{Preparasi klorofil alam}

Fabrikasi lapisan klorofil alam dilakukan melalui tahap ekstraksi, kromatografi, dan evaporasi seperti prosedur eksperimen yang telah dilakukan sebelumnya [14]. Tambahan prosedur yang tidak dilakukan pada eksperimen sebelumnya adalah prosedur evaporasi terhadap larutan hasil kromatografi selama 10 jam. Sedangkan Spirulina sp air tawar produksi PT Neoalgae Indonesia Makmur, Sukoharjo Jawa Tengah digunakan pada penelitian ini. Selanjutnya, hasil karakteristik tanpa prosedur evaporasi (sampel A) dan dengan prosedur evaporasi (sampel B) dibandingkan.

\section{Penumbuhan lapisan tipis dan karakterisasinya}

Pada tahap ini, larutan Spirulina sp akan dideposisikan di atas substrat PCB. Sebelum digunakan permukaan PCB dibersihkan dari lemak dan minyak akibat bersentuhan dengan jari. Pembersihan yang dilakukan yaitu dengan menggunakan acetone. Selanjutnya PCB tersebut dimasukkan kedalam alkohol $99 \%$ serta dibersihkan menggunakan ultrasonic cleaner 
selama 10 menit. Prosedur ini diulangi sebanyak 2 kali, dengan tujuan untuk memastikan bahwa permukaan PCB tersebut sudah bersih. Setelah bersih, PCB diangkat dan dibiarkan kering di udara bebas. Substrat PCB selanjutnya telah siap untuk digunakan pada deposisi lapisan tipis.

Penumbuhan lapisan Spirulina sp dilakukan dengan menggunakan metode spin coating menggunakan spin coater merk Chemat Technology KW-4A. Proses deposisi dilakukan dengan menggunakan kecepatan putar 500 rpm selama 15 sekon. Sedangkan proses drying dilakukan dengan temperatur $70^{\circ} \mathrm{C}$ selama 90 sekon. Variasi lapisan yang dilakukan dengan jumlah perulangan pelapisan $\mathrm{N}=1,2,3,4$ dan 5 .

Karakterisasi yang dilakukan pada penelitian ini meliputi pengamatan kurva absorbansi dengan Uv-Vis dan pengamatan karakteristik kelistrikan. Akhirnya karakteristik mobilitas pembawa muatan diamati dengan menggunakan I-V meter merk EL-KAHFI.

\section{HASIL DAN PEMBAHASAN}

Gambar 1 memperlihatkan grafik absorbansi dari larutan Spirulina $s p$ sebelum (sampel A) dan setelah dilakukan proses evaporasi hasil larutan kromatografi (sampel B) sebagai fungsi panjang gelombang. Absorbansi larutan Spirulina $s p$ dilakukan dengan menggunakan UV-VIS Spektrometer dengan panjang gelombang $400 \mathrm{~nm}-750 \mathrm{~nm}$. Hasil pengujian memperlihatkan bahwa kedua sampel memperlihatkan karakteristik yang sama. Tidak ada pergeseran puncak serapan dengan panjang gelombang yang mengindikasikan prosedur evaporasi larutan hasil kromatografi tidak mengakibatkan sampel berubah ataupun rusak.

Berdasarkan Gambar 1 dapat juga diamati bahwa pada interval $400 \mathrm{~nm}$ - $450 \mathrm{~nm}$ absorbansi sampel B lebih rendah dibandingkan hasil sampel A. Hal ini disinyalir terdapat molekul klorofil yang menguap ketika prosedur evaporasi dilakukan pada sampel B. Hasil ini pula menegaskan bahwa larutan diperoleh saat sintesis adalah klorofil.

Gambar 2 menunjukkan karakteristik dari fenomena transport (karakteristik I-V) pada lapisan Spirulina sp sampel A dan sampel $\mathrm{B}$ untuk $\mathrm{N}=3$. Berdasarkan grafik dalam Gambar 2 dapat teramati dengan jelas bahwa arus yang terukur meningkat secara linear mengikuti hukum Ohm. Semakin tinggi tegangan yang diberikan semakin tinggi pula arus yang dihasilkan. Kemiringan kurva mengindikasikan besarnya sifat kelistrikan dari sampel.

Kedua sampel teramati dengan jelas bahwa ketika tegangan yang diberikan sama dengan nol, namun arus yang terukur tidak sama dengan nol melainkan menunjukkan secara berurutan angka 1,5 nA dan $2 \mathrm{nA}$ untuk sampel sebelum (sampel A) dan setelah proses evaporasi (sampel B). Terukurnya arus pada saat tegangan sama dengan nol menunjukkan bahwa dalam sampel telah terdapat pembawa muatan intrinsik yang saling bergerak dan akan menghasilkan arus [15]. Pergerakan pembawa muatan yang semula acak ketika diberikan medan listrik eksternal maka pergerakannya menjadi teratur dan arahnya sesuai dengan arah medan listrik yang diaplikasikan, yang sering dinamakan sebagai drift current $[16,17]$.

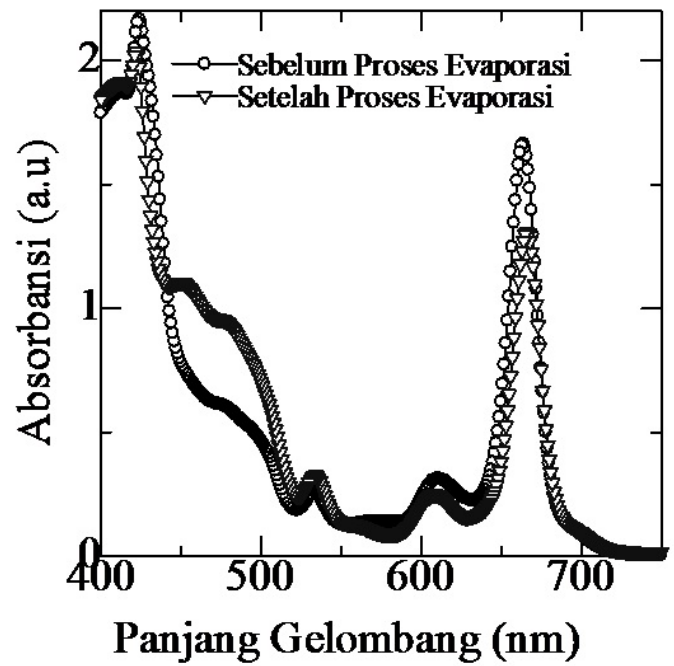

Gambar 1: Absorbansi larutan Spirulina sp: untuk larutan hasil kromatografi sebelum (sampel A) dan setelah (sampel B) proses evaporasi.

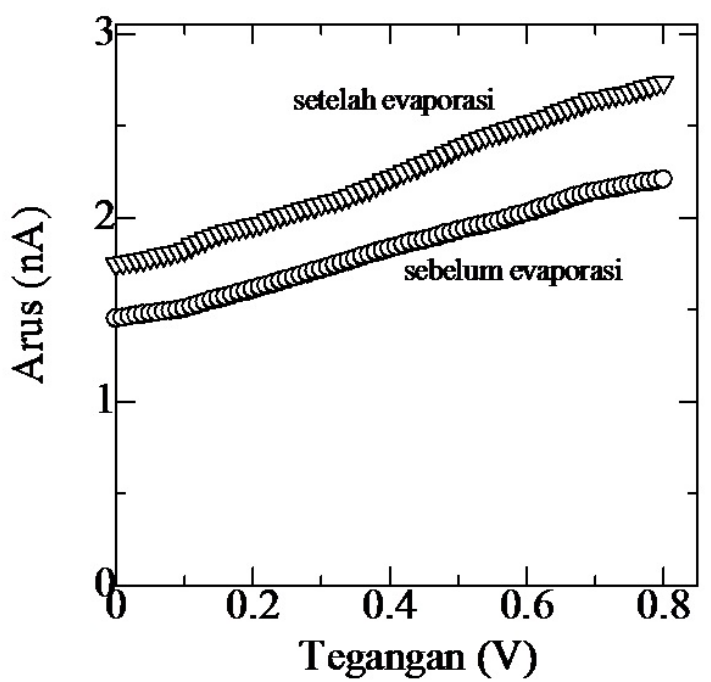

Gambar 2: Fenomena transport pada lapisan Spirulina sp dengan jumlah $\mathrm{N}=3$ untuk sampel $\mathrm{B}$ (setelah proses evaporasi) dan sampel A (sebelum proses evaporasi).

Arus yang terukur pada sampel hasil deposisi sampel B lebih tinggi bila di bandingkan dengan sampel A (Gambar 2). Hal tersebut dikarenakan setelah proses evaporasi diperoleh kandungan klorofil lebih murni, sehingga dapat diyakini bahwa konsentrasi chl-a sebagai pembawa muatan lebih berperan dalam fenomena transport yang terjadi pada lapisan hasil deposisi.

Nilai mobilitas pembawa muatan dari lapisan Spirulina $s p$ dapat ditentukan dari gradien grafik yang telah diperoleh. Mobilitas pembawa muatan menunjukkan kecepatan pembawa muatan yang bergerak dalam suatu medium tertentu dengan pengaruh medan listrik eksternal [15]. 


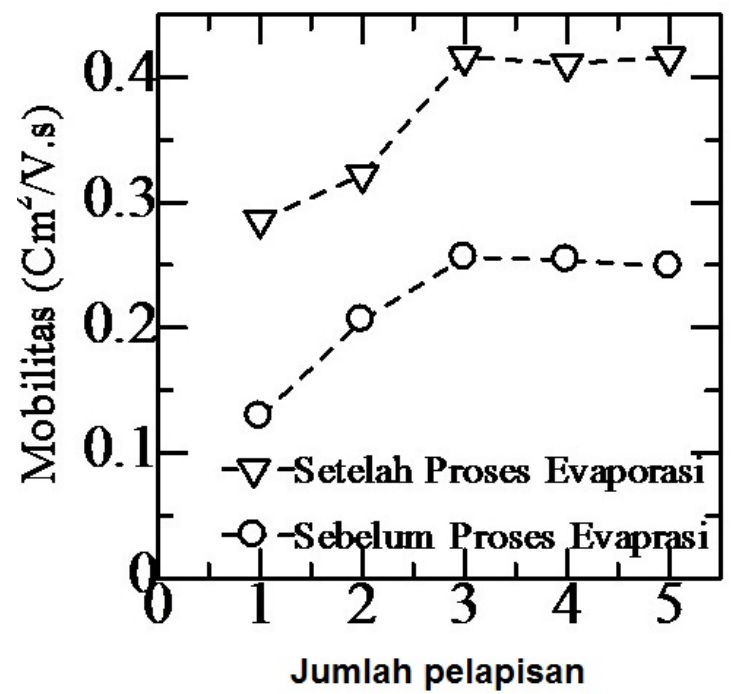

Gambar 3: Mobilitas pembawa muatan sebagai fungsi jumlah pelapisan.

Gambar 3 menunjukkan mobilitas pembawa muatan sebagai fungsi jumlah pelapisan $(\mathrm{N}=1 \infty 5)$. Dapat diamati bahwa mobilitas meningkat seiring dengan bertambahnya jumlah pelapisan Spirulina sp. Hal ini dikarenakan peningkatan jumlah lapisan akan meningkatkan jumlah populasi supra-molekul yang terdeposit sebagai lapisan tipis.

Mobilitas pembawa muatan dapat diamati dengan jelas bahwa setelah proses evaporasi (sampel B) lebih besar bila dibandingkan sebelum proses evaporasi (sampel A). Selain tingkat kemurnian klorofil sebagai pembawa muatan seperti yang dijelaskan sebelumnya, klorofom yang dipakai sebagai pelarut sampel B diduga menyebabkan mobilitas pembawa muatan lebih tinggi. Hal ini mengingat klorofom adalah pelarut yang efektif untuk senyawa organik dan bersifat polar, sehingga mean free path pembawa muatan sampel B lebih besar dibandingkan sampel A.

Mobilitas pembawa muatan pada lapisan sebelum dan setelah proses evaporasi kedua terlihat bahwa untuk $\mathrm{N}>3$ menunjukkan nilai yang konstan. Hal ini disumbang traping pembawa muatan yang dominan untuk jumlah perulangan lapisan lebih banyak [15]. Hasil nilai mobilitas $(\mu)$ yang didapatkan se-orde dengan hasil penelitian yang dipublikasikan [17].

\section{SIMPULAN}

Dari penelitian yang telah dilakukan didapatkan hasil bahwa mobilitas pembawa muatan untuk sampel B lebih tinggi dibandingkan sampel A. Tingkat kemurnian pembawa muatan setelah proses evaporasi disinyalir sebagai penyebab peningkatan mobilitas ini. Selain itu, mobilitas meningkat seiring peningkatan jumlah lapisan Spirulina $s p$ dan menunjukkan nilai konstan untuk $\mathrm{N}>3$ baik sampel A dan B. Hal ini disumbang traping pembawa muatan yang dominan untuk jumlah perulangan lapisan lebih banyak.
[1] S.I. Shin, et al., J. Porphyrins Phthalocyanines, 19, 517-526 (2015).

[2] S. Boussaad, A. Tazi, M.R. Leblanc, Journal of Colloid and Interface Science, 209, 341-346 (1999).

[3] S. Shanmugam, J. Xu, C. Boyer, Chemical Science, 10, 1039 (2014).

[4] J. Strumfer, M. Sener, K. Schulten, Journal of Physical Chemistry Latters, 3, 536-542 (2012).

[5] M. Etinski, M. Petkovic, M. Ristic, Original scientific paper, 78(11), 1775-1787 (2013).

[6] J. Benedito, et al., Journal of Chemical Physics, 138, 225102, 1-8 (2013).

[7] S. Boussaad, J.A. Derose, R.M. Leblanc, Chemical Physics Letters, 246, 107-113 (1995).

[8] L. Heng, et al., Science of the Total Environment, 530-531, 373382 (2015).

[9] N. Sheng, et al., Dyes and Pigments, 119, 116-121 (2015).

[10] Z. Xu, et al., Journal of Molecular Structure, 1094, 1-8 (2015).
[11] C. Jubert, G. Bailey, Journal of Cromatography, 1140, 95-100 (2007).

[12] N.L. Liu, et al., J. Appl. Phys. Lett., 105, 093719, 01-05 (2008).

[13] M.M. El- Nahass, et al., Synthetic Metals, 195, 110-116 (2014).

[14] F.F. Elvira, Karakterisasi morfologi permukaan dan fenomena magnetoconductance pada thin film porphyrin alam hasil deposisi spin coating, Skripsi, Jurusan Fisika FMIPA UNS, Surakarta, 2014.

[15] V. Podzorov, et al., Physics Review Letter, 93(8), 086602 (2004).

[16] F.L. Bloom, Exploring Organic Magnetoresistance An investigation of microscopic and device properties, Thesis, Technische Universiteit Eindhoven Belanda, 2010.

[17] J.U. Wallace, Carrier Mobility in Organic Charge Transport Materials: Methods of Measurements, Analysis, and Modulation, Partial Fulfillment of the Requirements for the Degree Doctor of Philosophy, University of Rochester, 2009. 